\title{
Exploiting Resources for Competitive Advantage of Cooperative Organizations in Malaysia
}

\author{
Rohana Othman ${ }^{1}$, Roshayani Arshad ${ }^{1}$, \\ Nooraslinda Abdul Aris², Siti Maznah Mohd Arif2. \\ ${ }^{1}$ Accounting Research Institute, \\ 2 Faculty of Accountancy, \\ Universiti Teknologi MARA, Shah Alam 40450, Malaysia. \\ rohana799@salam.uitm.edu.my, roshayani@salam.uitm.edu.my, \\ nooraslinda@salam.uitm.edu.my, maznah542@salam.uitm.edu.my
}

\begin{abstract}
Outstanding business performance and sustainable competitive advantage depend critically on tangible organizational resources, looking from the Resource-based view theory (Galbreath, 2004; Fahy, 2002). Lippman and Rumelt (2003) opined firms' assets (physical or financial) hold the potential to create peak value for competitive advantage, relatively free from the threat of being replicated. Firms are able to thwart threats by focusing on identifying and exploiting resources. This paper investigates the influence of organization's tangible resources on cooperative's success. Content analyses of annual reports of Malaysian cooperatives testify tangible internal resources are a viable business strategy for sustained competitive advantage positively impacting performance.
\end{abstract}

Keywords: Physical Resources, Cooperatives, Resource-based view (RBV) theory, Sustainability

eISSN 2398-4295 @ 2018. The Authors. Published for AMER ABRA cE-Bs by e-International Publishing House, Ltd., UK. This is an open-access article under the CC BY-NC-ND license (http://creativecommons.org/licenses/bync-nd/4.0/). Peer-review under responsibility of AMER (Association of Malaysian Environment-Behaviour Researchers), ABRA (Association of Behavioural Researchers on Asians) and cE-Bs (Centre for EnvironmentBehaviour Studies), Faculty of Architecture, Planning \& Surveying, Universiti Teknologi MARA, Malaysia.

DOI: http://dx.doi.org/10.21834/ajbes.v3i12.124 


\subsection{Introduction}

Serving as the third engine of growth after the public and private sectors, cooperatives are acknowledged to contribute significantly ( $10 \%$ by 2020$)$ to the socio-economic growth and development of Malaysia (MTDC website). The National Cooperative Policy (2011- 2020) is aimed to drive Malaysia's transformation to high-value added and high-income economy without sacrificing financial stability.

The success of cooperative organizations is critically dependent on their ability to sustain competitive advantage and achieve superior firm performance. Almarri \& Gardiner (2014) concluded resources deployed to create value for customers improve sustainable competitive advantage thus leading to superior performance. Cooperatives must remain competitive, relevantly providing dynamic operations and deploying competitive advantage strategies and are effective self-help organizations upholding environmental sensitivity (Leonidou et al., 2013). Firms can generate superior performance by implementing effective and successful strategies derived from keen awareness and understanding of their key competitive advantage (Wernerfelt, 1984; Barney, 1986).

Prior studies verify firms possess resources that provide the potential for competitive advantage which subsequently lead to superior performance (Wernerfelt, 1984). Extant literature shows the concept of RBV is a useful tool to investigate the relationship between firm resources and firm success. This relationship has been widely explored across many industries but not so among cooperative organizations. According to Meutia \& Ismail (2012), the foundations of a firm's progress, profitability and sustained competitive advantage would normally be reflected through its resources. They emphasized that firms have different categories of resources and the application of this strategic tool allow for the possibility of a different path to growth. Firms can deploy its resources in strategies and policies that will make the firms more efficient and effective (Wernerfelt, 1984). Wernerfelt (1984) suggested that idiosyncratic, immobile strategic resources owned or controlled by a firm were potential sources of competitive advantage. In this context, it is realistic both in theory and practice, to examine the relationship between resources and cooperative performance.

Ironically very little work has been done to test elements of RBV empirically in the context of cooperative organizations, while available studies concentrated on the relationship between intangible assets or capabilities and firm performance. According to Foss (1997), RBV research would gain more utility by expanding the range of resources to cover tangible and intangible resources. Foss (1997) cited several cases where physical assets or tangible resources derive sustainable competitive advantages to firms. Therefore, this paper aims to examine the relationship between tangible resources and firms' performance. The results will support arguments for tangible assets contribute significantly to competitive advantage.

This study will reveal competitive advantage as evidence of business success among cooperative organizations, providing the cooperative movement in Malaysia an avenue to achieve its original intent to provide economic, financial and social benefits to members and society. 


\subsection{Literature Review}

Extant literature on RBV categorizes various forms of resources. Barney (1991) classified resources into physical capital resources, human capital resources and organizational capital resources. According to RBV, resources comprise physical assets, intangible assets, and organizational capabilities that the firm owns and controls (Wernerfelt, 1984). Capabilities comprise latent competencies or expertise employed in organizations operations supported by accumulated knowledge (Day, 1994). They further reiterated, capabilities represent a prime and most essential indefinite open ended firm resource that are resistant to being replicated. Resources are either tangible (e.g. financial or physical) or intangible (e.g. employee's knowledge, experiences and skills and firm's reputation) and mobilized to attain sustainable competitive advantage (Galbreath, 2004; Grant, 2002). Wernerfelt (1984) posits companies gain competitive advantage through resources, tangible and intangible. Intangible resources are by nature, diverse and immobile, with individualistic disposition and are easily duplicated.

Inmyxai and Takahashi, (2010) emphasized that the firm can expect to increase production, services, and business operations with the use of physical resources incorporated with sophisticated technology. Firms that consistently make prudent choices about the acquisition and deployment of the resources have a history of successfully employing its physical assets to gain competitive advantage. Correspondingly, a firm's likelihood towards breakthrough transactions hinges on the availability of financial resources, and conversely, a firm may be curtailed towards innovating strategies when financial resources are limited (Lee et al., 2001).

Greco, Cricelli \& Grimaldi (2013) highlighted physical resources alone is insufficient to maximize profits. Financial resources, which include, financial liquidity, operating funds and borrowing capacity and firm's ability to generate internal funds, is also vital for a stable and successful firm enjoying maximum profitability (Volerda et al., 2011). Two key components of financial resources are current assets and business finance. Current assets that include cash, accounts receivable, inventory, marketable securities, prepaid expenses and other liquid assets possess liquidity and are more readily convertible into cash and are therefore, paramount to cash flow management and forecasting. However, current assets offer relatively small amounts of liquidity on a short-term basis, mainly to address cash flow problems. The absence of sufficient funds to repay short term liabilities may induce payouts from permanent capital thus risking the company to go bankrupt. Hence, the firm's ability to pay short-term liabilities is a key factor in determining the performance of a firm. Inmyxai and Takahashi (2010) identified business finance is an essential factor for financing strategic resources and restructuring or expanding the business in line with the business objective of profit maximization. Among cooperative organizations, business finance depends heavily on membership fees and members shares. Members can exploit advantages in membership fees and members shares to gain competitive advantage as evidenced by superior rates of return (Barney, 1986).

In this study, tangible resources are classified to include both physical resources and financial resources of cooperative organizations, which are expected to affect performance. Inmyxai and Takahashi, (2010) opined that tangible assets may still have a significant role in 
the performance of firms. Galbreath (2004) noted that tangible assets provide higher utility towards a firm's success compared to intellectual property. In addition, Lippman and Rumelt, (2003) and Kazozcu (2011) stressed firms capable of creating above average utility value of their assets; financial or physical are well positioned to mobilize these assets for a competitive edge, enjoying minimal threats of being replicated. Inmyxai \& Takahashi (2010) argued that tangible resources have more profound effect on firm performance compared to intangible resources. This is consistent with the findings of Galbreath (2004) and Fahy (2002) who found that tangible resources have a significant impact on firm performance compared to intangible resources. Based on these studies, we can hypothesize that tangible assets has an impact on the performance:

$\mathrm{H1}$ : Tangible resources have positive significant influence on performance of cooperative organizations.

H1a: Physical resources have positive significant influence on performance of cooperative organizations.

$\mathrm{H} 1_{\mathrm{b}}$ : Current assets have positive significant influence on performance of cooperative organizations.

$\mathrm{H} 1_{\mathrm{c}}$ : Business finance has positive significant influence on performance of cooperative organizations.

The outcome of this study will contribute to the realization that tangible resources also a major role on companies' sustainability.

\subsection{Methodology}

\subsection{Sample and Data Collection}

The sample for this study consists of 39 cooperatives registered in Malaysia. The research employs an approach that involves content analysis of the cooperatives' annual reports.

\subsection{Empirical Schema}

The relationships developed in hypotheses $\mathrm{H} 1_{a}, \mathrm{H} 1_{b}$, and $\mathrm{H} 1_{c}$ are depicted in an empirical schema as given in Figure 1. In addition to the identified independent variables, this study also includes total liabilities as control variable. The definitions and measurements of variables used in this study are outlined in Table 1. 


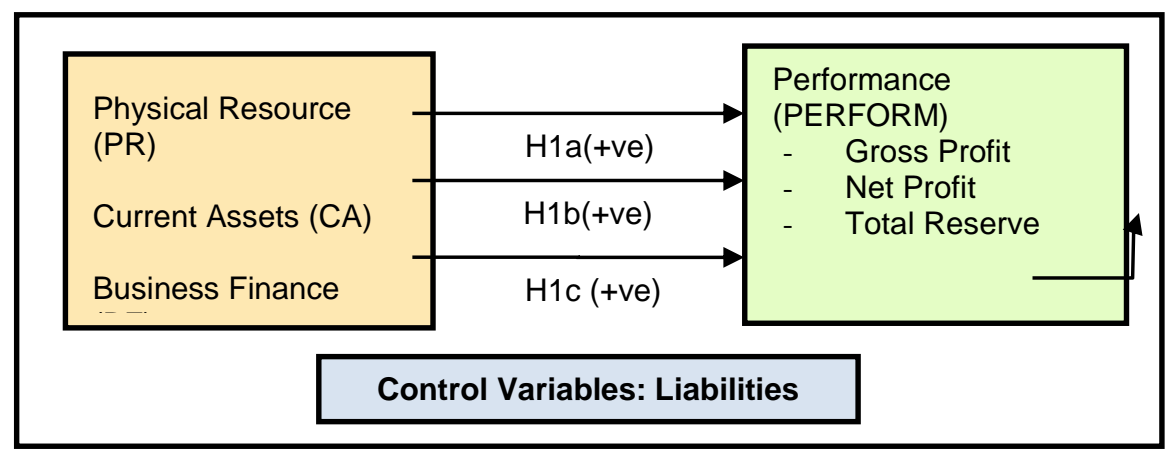

Figure 1: Empirical Schema of Proxies for the Resource-Based View Theory on Performance

Table 1: The definitions and measurements of variables used in this study

\begin{tabular}{lll}
\hline $\begin{array}{l}\text { Variable } \\
\text { Acronym }\end{array}$ & Definition & \multicolumn{2}{c}{ Measurement } \\
& & Based on: \\
PERFORM & Performance & $\bullet \quad$ Gross profit \\
& & $\bullet \quad$ Net profit \\
PR & Physical & Total fixed assets such as land and building, plant, \\
CA & Resource & and equipment \\
BF & Current Assets & Total current assets \\
TL & Business & Total members fees and members share \\
\hline
\end{tabular}

\subsection{Results and Discussions}

\subsection{Descriptive Statistics}

Table 2 provides descriptive statistics of the variable PERFORM and the independent variables. PERFORM in this study is based on three types of revenues: gross profit, net profit and total reserves. The mean values are RM94,592,639.70, RM51,166,113.83 and RM70,799,173.33 respectively. However, the minimum negative values for gross profit and net profit indicate that some cooperatives in the sample made gross loss and net loss during the year of the study. The mean values for physical resource are RM1,502,003,859.43. In relation to financial resource, the mean value for current assets and business finance are RM170,849,463.64, which is relatively lower to the mean values of tangible assets and total assets.

Table 2: Descriptive Statistics for the dependent and continuous independent variables

\begin{tabular}{llll}
\hline & Minimum & Maximum & Mean \\
\hline Total Reserve & 0.00 & $2,363,011,000.00$ & $70,799,173.33$
\end{tabular}




$\begin{array}{lrrr}\text { Gross Profit } & -4,642,940.29 & 3,295,290,000.00 & 94,592,639.70 \\ \text { Net Profit } & -7,045,854.69 & 1,729,775,000.00 & 51,166,113.83 \\ \text { Physical Resource } & 0.00 & 56,477,382,000.00 & 1,502,003,859.43 \\ \text { Current Assets } & 0.00 & 5,599,732,000.00 & 170,849,463.64 \\ \text { Total Liability } & 0.00 & 55,886,651,000.00 & 1,465,500,416.34 \\ \text { Members Fee \& } & 0.00 & 1,994,960,000.00 & 99,005,044.90 \\ \text { Members Share } & & \end{array}$

\subsection{Multivariate Analysis}

In this study, linear multiple regression is used as the basis of analysis for testing $\mathrm{H} 1 \mathrm{a}$ to $\mathrm{H} 1 \mathrm{c}$. The hypothesized relationships are modeled as follows.

\section{PERFORM $=\beta_{0}+\beta_{1} P R+\beta_{2} C A+\beta_{3} B F+\beta_{4} T L+\varepsilon t$ Where variable definitions are given in Table 1.}

In the above regression model, multicollinearity was tested using the variance inflation factor and tolerance levels, and found to be well within the satisfactory range. In addition to these tests, an analysis of the Kolmogorov-Smirnov (K-S Lilliefors) and the Shapiro-Wilk normality test statistics suggests that the dependent variables and continuous independent variables are not distributed normally. As such, these variables are transformed by computing normal scores using Van der Waerden's transformation. A regression analysis is performed with the transformed variables.

\subsection{Discussions}

Table 3 presents the regression analysis results. In terms of tests of each of the hypotheses Table 3 showed the adjusted $R^{2}$ are $0.780,0.821$ and 0.687 for factors influencing performance (total reserve, gross profit, and net profit respectively) of cooperatives in the sample of the study. $\mathrm{H} 1_{\mathrm{a}}$ predicts the availability of physical resource is significantly positively related to performance. The results in Table 3 reveal a positive and significant relationship of PR only for performance as measured by Total Reserve. Thus $\mathrm{H} 1 \mathrm{a}$ is only partially accepted. The insignificant relationships between PR and performance based on gross profit and net profit indicate that cooperatives are not capitalizing on their physical resource in enhancing their revenues generated from their operations.

Table 3: Multiple Regression Results for Factors Affecting Performance of Cooperatives

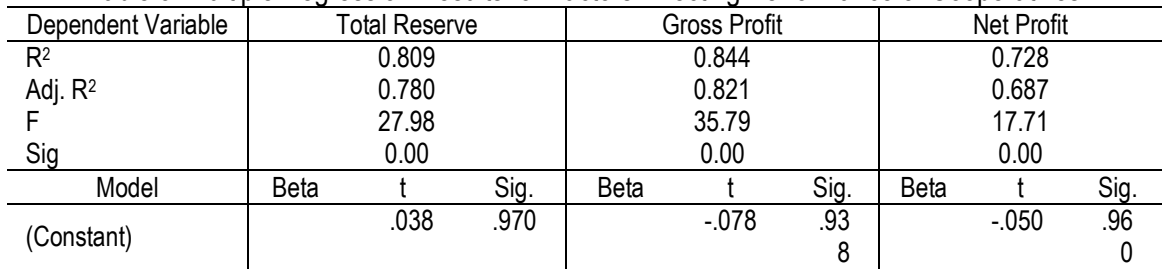


Othman, R., et.al. / Asian Journal of Behavioural Studies (AjBeS), 3(12) Jul / Aug 2018 (p.63-71)

\begin{tabular}{l|rrr|rrr|rrr} 
Physical Resource & .896 & 3.623 & .001 & .136 & .609 & .54 & - & -.407 & .68 \\
$\begin{array}{l}\text { (PR) } \\
\text { Current Assets (CA) }\end{array}$ & .952 & 2.017 & .052 & .947 & 2.220 & .03 & .460 & .816 & .42 \\
& & & & & & 3 & & & 0 \\
Total Assets (TA) & -.914 & - & .143 & - & -1.554 & .13 & - & -.263 & .79 \\
& & 1.499 & & .855 & & 0 & .191 & & 4 \\
Total Liability (TL) & -.790 & - & .001 & .374 & 2.010 & .05 & .314 & 1.279 & .21 \\
$\begin{array}{l}\text { Member Fee + } \\
\text { Member Share (BF) }\end{array}$ & .754 & 4.839 & & & & 3 & & & 0 \\
\hline
\end{tabular}

On the other hand, it is also possible the cooperatives in the sample of the study do not have sufficient amount of physical resource to operate at an efficient level. The availability of extra resources has been argued in past studies (Chiu \& Liaw, 2009) as central to an organization, enabling the organization to adapt to internal and external pressures, as well as to initiate any strategic changes required in enhancing its performance.

$\mathrm{H} 1_{b}$ predicts the availability of $\mathrm{CA}$ is significantly positively related to performance. The results in Table 3 reveal a positive and significant relationship of CA only for performance as measured by gross profit. Based on these results, $\mathrm{H}_{\mathrm{b}}$ is only partially accepted. The positive and significant relationship of CA and gross profit indicates that the cooperatives are using their current assets in maximizing revenues generated from operations. However, these results indicate that the cooperatives are not able to utilize their current assets in safeguarding their organizations from making net losses or enhance their net profits.

Finally, $\mathrm{H} 1$ c predicts the availability of business finance is significantly positively related to performance. Results in Table 3 indicate significant relationships between BF and performance based on gross profit, net profit and total reserves. Hence, $\mathrm{H} 1_{\mathrm{c}}$ is accepted. Business finance includes member's shares and member fees. The significant results indicate that the cooperatives are utilising and developing their financial resources in creating competitive advantage that is crucial in enhancing firm performance.

\subsection{Conclusion}

The availability of tangible resources in cooperatives and their influence on firm performance is considered essential for organizations as it can help to develop the resources and capabilities crucially needed to adapt to their external environment and in so doing facilitate organizations to achieve continuous growth. This study obtained result that indicate cooperatives utilize more of their corporate resources to create competitive advantage positively impacting firm performance.

RBV asserts organizations generate competitive advantage, mainly using the organization's resources, in particular those valuable, rare, and hard to substitute resources (Barney, 1991). Hence, the uniqueness and distinctiveness of these resources deserve close scrutiny. To achieve competitive advantage, companies have to vigilantly analyze their internal strengths and weaknesses to exploit these resources. For examplee, company's tangible resources such as organizational slack in developing innovations in the form of 'environmental friendly products, 'animal-free testing', 'pollution prevention policy' and 
investment on research and development can be utilized for competitive advantage because they can distinguish a company from its competitors. Consequently, these products will lead to improvements in financial performance.

This study endured some limitations, firstly when focusing only on the relationship of tangible assets to firm performance. Future research may consider other components of corporate resources such as intellectual and reputational assets. The sample in this study is relatively small lending credence for future research to consider a larger number of samples and conduct observations over several accounting periods. This would allow a more meaningful measure of extra tangible resources compared to this study, hopefully leading to a more meaningful examination on the enhancement of firm performance.

\section{Acknowledgement}

The authors would like to express their gratitude to the Ministry of Education, the Accounting Research Institute, and the Faculty of Accountancy, Universiti Teknologi MARA (UiTM), Malaysia for providing the financial means and facilities. This article would not have been possible without their support.

\section{References}

Barney, J. (1991). Firm resources and sustained competitive advantage. Journal of Management, 17(1), 99-120.

Barney, J. B. (1986). Strategic factor markets: Expectations, luck, and business strategy. Management Science, 32(10), 1231-1241.

Almarri,K. and Gardiner, P. (2014). Application of resource-based view to project management research: supporter and opponents. Procedia - Social and Behavioral Sciences. Vol. 119, p.437-445.

Greco, M. Cricelli, L. \& Grimaldi, M. (2013). A strategic management framework of tangible and intangible assets. European Management Journal, 31, 55-66.

Chiu, Y. C., \& Liaw, Y. C. (2009). Organizational slack: is more or less better?. Journal of Organizational Change Management, 22(3), 321-342.

Day, G. S. (1994). The capabilities of market-driven organizations. The Journal of Marketing, 37-52.

Fahy, J. (2002). A resource-based analysis of sustainable competitive advantage in a global environment. International Business Review, 11(1), 57-78.

Foss, N. J. (Ed.). (1997). Resources, firms, and strategies: a reader in the resource-based perspective. Oxford University Press.

Galbreath, J. (2005). Which resources matter the most to firm success? An exploratory study of resource-based theory. Technovation, 25(9), 979-987.

Galbreath, J. T. (2004). Determinants of Firm Success: A Resource-based Analysis. Curtin University of Technology.

Grant R.M (2002). Contemporary strategy analysis; concept, technique, applications (4th ED). Mssachusetts: Blackwell 
Inmyxai, S., \& Takahashi, Y. (2010). The effect of firm resources on business performance of male-and femaleheaded firms in the case of Lao micro-, small-, and medium-sized enterprises (MSMEs). International Journal of Business and Information, 5(1), 63-90.

Kazozcu, S.B. (2011). Role of strategic flexibility in the choice of turnaround strategies: A resource based approach. Procedia - Social and Behavioral Sciences. Vol. 24, p.444-459.

Lee, C. Lee, K. Pennings, J.M. (2001). Internal Capabilities, external networks, and performance: a study on technology-based ventures. Strategic Management Journal. Vol. 22, issues 6-7. P.615-640.

Leonidou, L. C., Leonidou, C. N., Fotiadis, T. A., \& Zeriti, A. (2013). Resources and capabilities as drivers of hotel environmental marketing strategy: Implications for competitive advantage and performance. Tourism Management, $35,94-110$.

Lippman, S. A., \& Rumelt, R. P. (2003). A bargaining perspective on resource advantage. Strategic Management Journal, 24(11), 1069-1086.

Meutia and Ismail, T. (2012). The Development of Entrepreneurial Social Competence And Business Network to Improve Competitive Advantage And Business Performance of Small Medium Sized Enterprises: A Case Study of Batik Industry In Indonesia. Procedia - Social and Behavioral Sciences, 65, 46 - 51.

MDTC (2010). The National Cooperative Policy 2011-2020 [pdf]. Retrieved from http:// http://www.skm.gov.my/Gerakan-Koperasi/Dasar-Koperasi-Negara-2011-2020.aspx

Wernerfelt, B. (1984). A resource-based view of the firm. Strategic management journal, 5(2), 171-180. 